\title{
MEMÓRIA DE SALA DE AULA
}

Vera Casa Nova

(UFMG)

\begin{abstract}
Escrever para lembrar? Não para me lembrar, mas para combater a dilaceração do esquecimento na medida em que ele se anuncia como absoluto... (Roland Barthes)
\end{abstract}

Dirce Côrtes Riedel, Angela Vaz Leão, Maria Luiza Ramos, Bela Josef, Cleonice Berardinelli, Maria do Carmo Pandolfo. Mulheres da literatura com que me deparei durante minha vida acadêmica, no Rio de Janeiro e em Belo Horizonte. Hoje presto minha homenagem a quem me ensinou Literatura Brasileira, lições de literatura e de vida: Dirce Côrtes Riedel.

Dirce foi minha professora na UEG (hoje, UERJ), Faculdade de Letras, ali na rua Haddock Lobo, em 1967 e1968. Anos turbulentos.

Entrava em sala uma baixinha miúda, com voz forte, sorriso no canto da boca, falando de Machado de Assis. Como ninguém, ia desfiando crítico a crítico, mostrando um aspecto ou outro na abordagem da obra de Machado. Era uma paixão que deixava rastros em seus alunos. Lembro de Ivan Proença, Lucia Helena entre outros tantos que assistiam com entusiasmo suas aulas, com suas análises instigantes.

Como ler o texto literário? Essa pergunta durante muitos anos foi meu leitmotiv em sala de aula. Pergunta que sempre me remetia à obra teórica de Roland Barthes e que me foi apresentado por Dirce através do livro Elementos de Semiologia. Mas havia o New criticism, o formalismo russo, o Círculo Linguístico de Praga, Georg Luckács. As teorias eram indicadas para que pudéssemos ler melhor os autores brasileiros.

Dirce, além de professora, era uma intelectual, uma pensadora e se dava como tarefa ver o seu tempo. Com os olhos sobre a História inquietava-se em ver o que a ditadura militar nesses anos de 1960 tinha 
praticado contra os brasileiros e como a cegueira de seus contemporâneos se evidenciava.

Dirce lutava contra essa cegueira no meio estudantil durante suas aulas de literatura brasileira, entre um comentário e outro. Nessa época eu participava da equipe do Jornal $O$ Corujão, com sua equipe, Adilson Monteiro, Arthur Carlos Tinelli, e outros. Esse jornal pertencia ao Diretório Acadêmico e se caracterizava pela radicalidade na militância de esquerda. Radicalidade que nos levaria todos, inclusive os articulistas, ao DOPS, da rua da Relação.

DOPS de péssima memória. No mesmo processo estavam eu, Dirce, Ivo Barbieri e Terezinha, sua esposa, também professora de literatura brasileira.

Lembrar das aulas de Dirce e de toda essa época, cinquenta anos depois, com a lembrança daqueles dias de horror é pensar no nosso holocausto. Prédio invadido pela polícia, estudantes, colegas, presos e alguns desaparecidos, passeatas, bombas de gás lacrimogêneo..." pra não dizer que não falei de flores"... E caminhando íamos nós...

Entre a radicalidade político-ídeológica e as ambiguidades, as metáforas e as metonímias, as narrativas literárias se sucediam. E Dirce se multiplicava em aulas, que abordavam não só literatura, mas sobretudo o olhar crítico sobre a sociedade brasileira.

Mas mesmo quando a memória falha, os rastros se sucedem, e aqui vou me lembrando, fazendo um esforço que possibilite a imagem dela retornar. Muitas aulas foram assistidas no prédio do Colégio de Aplicação da UEG, situado na Rua do Bispo. Dirce nos levava a pensar sobre o silêncio, que como em coro insistia em nos desesperar, quando nos obrigavam a calar.

Falava-se de uma crise (política) do ensino. Jarbas Passarinho, então ministro da Educação, entre outros coronéis e generais, dizia a nós, futuros professores, o que devíamos ensinar em nossas aulas. E Dirce nos interpelava, questionando os discursos sobre educação e cultura, e mais sobre o discurso do professor em sala de aula, "aquele que fala para alguém que não fala".

A cada aula, o transfert se instituía. Ficávamos com os restos de um saber que a todo momento se insinuava. As aulas eram cenas em que os atores experimentavam territórios imprecisos, onde os murmúrios dos signos diziam de nossa impotência. 
Somente o desejo de ir além do que ouvíamos dizer. Dirce não se contentava com esse ouvir dizer. Como sair dessa dialética entre o que se dizia e o oculto? Em cada notícia sobre prisões e torturas de colegas ou professores mostrava-se o horror. O grito calado era visível, ou melhor, ouvível, durante as aulas.

Nessa época Roland Barthes mais uma vez aparecia num texto levado por Dirce para a sala de aula: Escritores, escreventes... Depois desse dia, nunca mais deixei de lê-lo.

A imagem de Dirce retorna. Percorrer terras alheias, produzindo sentidos, inventando possibilidades de leituras, tentando "destruir os estereótipos", "as necroses da linguagem", a tagarelice da crítica da época. Era um verdadeiro exercício de Semiologia. Estruturalismo? Dirce não se apegava a rótulos, desconstruía-os.

Lendo Machado de Assis, anotando as aulas de Dirce. Já não as encontro, perderam-se no tempo, nas folhas do fichário da papelaria União, a papelaria da rua do Ouvidor.

Lendo Guimarães Rosa, no meio do sertão, em Grande sertão: veredas. Sobre Riobaldo e Diadorim ficaram muitas anotações na marginália do livro: rabiscos, frases sublinhadas, comentários de Dirce. Meu exemplar de GSV da Editora José Olympio, com ilustrações de Poty, também desapareceu da estante de minha biblioteca,mas as reminiscências persistem. Rasuras significantes em minha vida de professora de teoria da literatura e literatura brasileira.

Literatura é vida? O corpo que escreve, a voz que perde sua origem,o autor que entra na sua própria morte quando a escrita começa... tudo entre aspas, mas com o grão da voz de Dirce ficava tudo novo, a partir da Morte do autor, texto de Roland Barthes, de 1968.

O corpo que escreve, o corpo que lê...

Pela primeira vez ouvíamos falar em intransitividade do texto literário. Não mais a Estilistica daqueles tempos, mas uma outra abordagem, a semio-crítica em que os olhos de Capitu seriam o significante maior do texto de D. Casmurro, ou " o diabo na rua, no meio do redemoinho" no texto de GSV.

Travessia, Nonada, significantes com que Dirce brincava conosco em suas aulas rosianas. Ir até o "rabo das palavras" e aprender a escrever nossa leitura, deixando o plural acontecer. Inesquecíveis aulas.

Tempo e espaço, cuja memória vai aos poucos se apagando, dissipando-se. Quase bruma. O gadget não tem acesso a essa memória. Lutar 
contra o apagamento é tarefa difícil, resistir é sempre possível. Abrir os olhos da memória e deixar que meu olhar faça a imagem de Dirce retornar.

Outro momento, anos depois, na década de 1980, numa banca de concurso para professores de literatura na Faculdade de Letras da UFMG, encontrei minha velha professora. Mais uma vez Barthes nos unia. Aprovada. Depois desses dias de prova, nunca mais vi Dirce. Hoje, quando passo pela rua Haddock Lobo, vejo somente o colégio Lafayette. Ao lado, o prédio da Letras não existe mais.

Recebido em: 14 de outubro de 2016

Aceito em: 22 de outubro de 2016 